\title{
SYNTHESIS OF THREE NEW VIC-DIOXIMES AND THEIR NICKEL(II) AND COPPER(II) COMPLEXES
}

\author{
ERSIN GULER \\ Selçuk University, Faculty of Arts and Sciences, Department of Chemistry, 42075 Konya, Turkey
}

(Received: March 10, 2008 - Accepted: January 28, 2009)

\begin{abstract}
In this study, anti-1-acetyl-1-cyclohexenylchloroglyoxime $\left(\mathrm{C}_{8} \mathrm{H}_{11} \mathrm{ClN}_{2} \mathrm{O}_{2}\right)$ has been synthesized by chlorination of anti-1-acetyl-1-cyclohexeneglyoxime. As a result of the reaction of $\mathrm{C}_{8} \mathrm{H}_{11} \mathrm{ClN}_{2} \mathrm{O}_{2}$ with aryl- or arylalkylamines in ethanol between $-10{ }^{\circ} \mathrm{C}$ and $-15{ }^{\circ} \mathrm{C}$, unsymmetrical vic-dioximes were obtained and the obtained products were named as: anilino-1-acetyl-1-cyclohexeneglyoxime $\left(\mathrm{C}_{14} \mathrm{H}_{17} \mathrm{~N}_{3} \mathrm{O}_{2}\right)$, benzylamino -1-acetyl-1-cyclohexeneglyoxime $\left(\mathrm{C}_{15} \mathrm{H}_{10} \mathrm{~N}_{3} \mathrm{O}_{2}\right)$, p-toluidino -1-acetyl-1-cyclohexeneglyoxime $\left(\mathrm{C}_{15} \mathrm{H}_{10} \mathrm{~N}_{3} \mathrm{O}_{2}\right)$ respectively. Their transition metal complexes have been synthesized. The form of the obtained $\mathrm{Ni}(\mathrm{II})$ and $\mathrm{Cu}(\mathrm{II})$ complexes were found as square-planer as it is known usually. ${ }^{1} \mathrm{H}$ n.m.r., conductivity measurements, magnetic properties, i.r spectra and elemental analyses data of ligands and complexes are given. In addition to this, thermal characterizations of the ligands and their complexes have been investigated.
\end{abstract}

Key Words: Copper(II), Ligands, Nickel(II), Oximes, vic-dioximes,

\section{INTRODUCTION}

Vic-dioximes have received considerable attention as model compounds which mimic bifunctions such as the reduction of $\mathrm{B}_{12}{ }^{1,2}$. Oxime metal chelates are biologically active ${ }^{3}$ and are reported to possess semiconduction properties ${ }^{4,5}$. Derivates of some momoaminoglyoxime, vic-dioximes, tetraoximes and their transition metal complexes have been described ${ }^{2,6-16}$.

Nowadays, vic-dioximes are appreciated as coordination compounds in lots of usage areas such as analytical, biologically, pigment and medicinal chemistry. Many researchers have studied vic-dioximes, and the important role of the complexes especially 1,2-dioximes in coordination chemistry ${ }^{4,5}$. The substitution pattern of vic-dioxime moiety affects the structure and stability of the complexes ${ }^{4-8}$, but the complexes are decomposed in the case of aminoglyoxime derivates ${ }^{17}$. In the present paper, I report the synthesis of and complex formation by two new substituted amino-1-acetyl-1-cyclohexeneglyoximes as examples of unsymmetrically substituted vic-dioximes. The unssymmetry of the ligands is also expected to enhance the solubility of planar complexes derived from them.

\section{EXPERIMENTAL SECTION}

\section{Materials and methods}

1-acetyl-1-cyclohexene was bought ready-made from Merck. Anti-1acetyl-1-cyclohexeneglyoxime was prepared by reported procedures ${ }^{13,17-19}$. M.p.s.'s were measured on an Electrothermal IA 9100 digital melting point apparatus. Elemental analyses $(\mathrm{C}, \mathrm{H}$ and $\mathrm{H})$ were realized using a Carlo-Erba 1106 model analyzer. ${ }^{1} \mathrm{H}$-n.m.r. and i.r. spectras were obtained with Bruker 200 $\mathrm{MHz}$ spectrometer and Jasco FT/I.r-300 instrument, respectively. The $\mathrm{pH}$ of the solutions were adjusted and controlled with WTW pH.537 pH meter. Molar conductance of the ligands and their metal complexes were determined at room temperature using a CMD 750 WPA conductivity meter. TGA curves were recorded on a Shimadzu TG-50 thermo balance.

Synthesis

Anti-1-acetyl-1-cyclohexenechloroglyoximes, anti- $\mathrm{C}_{8} \mathrm{H}_{1 I} \mathrm{ClN}_{2} \mathrm{O}_{2}$

Dry chloro gas was passed through a suspension of anti-1-acetyl-1-cyclohexeneglyoxime $(3.36 \mathrm{~g}, 0.020 \mathrm{~mol})$ in $30 \mathrm{~mL}$ chloroform under sun light for $1 / 2 \mathrm{~h}$ until the color of suspended material became grey. After the transition of $\mathrm{Cl}_{2}$ for $2 \mathrm{~h}$ under UV-irradiation ( $254 \mathrm{~nm}$ ), it was observed that the temperature of the mixture reached $35^{\circ} \mathrm{C}$ and crystals formed. The mixture was cooled to room temperature, excess $\mathrm{Cl}_{2}$ was expelled in vacuum and then the solution was filtered and the solid was washed with chloroform and then water. By the recrystalization in ethanol-water $(1: 2) 3.95 \mathrm{~g}(\% 78)$ product was gained with m.p. as $130^{\circ} \mathrm{C}$.

It was determined that this obtained compound was soluble in ethanol, DMSO, DMF and diethyl ether but insoluble in water.

Synthesis of Substituted Amino-1-acetyl-1-cyclohexeneglyoximes $\left[\mathrm{L}^{1} \mathrm{H}_{2}\right]$, $\left[\mathrm{L}^{2} \mathrm{H}_{2}\right]$ and $\left[\mathrm{L}^{3} \mathrm{H}_{2}\right]$
The solution of $0.01 \mathrm{~mol}$ freshly distilled amino compounds such as [aniline $(2 \mathrm{~mL})$, benzylamine $(2.2 \mathrm{~mL})$, p-toluidine $(1.07 \mathrm{~g})]$ in absolute ethanol $(30 \mathrm{~mL})$ was added to a stirred of anti- $\mathrm{C}_{8} \mathrm{H}_{11} \mathrm{ClN}_{2} \mathrm{O}_{2}$ (2.025 g, $\left.0.01 \mathrm{~mol}\right)$ in absolute ethanol $(35 \mathrm{~mL})$ between $-10{ }^{\circ} \mathrm{C}$ and $-15{ }^{2} \mathrm{C}$ drop by drop in $30 \mathrm{~min}$. The reaction mixture was further stirred for $2 \mathrm{~h}$ and then diluted with water to $120 \mathrm{~mL}$ and left overnight at $5{ }^{\circ} \mathrm{C}$. The precipitate was filtered and then recrystallized from ethanol-water $(1: 2)$. The crysalline product was filtered, washed with water and dried at room temperature.

\section{Synthesis of the $\mathrm{Ni}(\mathrm{II})$ and $\mathrm{Cu}(\mathrm{II})$ Complexes}

When a solution of $0.6 \mathrm{mmol}$ metal salt $\left[\mathrm{NiCl}_{2} \cdot 6 \mathrm{H}_{2} \mathrm{O}(0.143 \mathrm{~g}), \mathrm{CuCl}_{2} 2 \mathrm{H}_{2} \mathrm{O}\right.$ $(0.103 \mathrm{~g})]$ in $25 \mathrm{~mL}$ absolute ethanol was added into a solution of the ligand $(1.2 \mathrm{mmol})\left[\mathrm{C}_{14} \mathrm{H}_{17} \mathrm{~N}_{3} \mathrm{O}_{2}(0.311 \mathrm{~g}), \mathrm{C}_{15} \mathrm{H}_{19} \mathrm{~N}_{3} \mathrm{O}_{2}(0.328 \mathrm{~g}), \mathrm{C}_{15} \mathrm{H}_{19} \mathrm{~N}_{3} \mathrm{O}_{2}(0.328 \mathrm{~g})\right]$ dissolved in $25 \mathrm{~mL}$ of ethanol, the $\mathrm{pH}$ of the mixture changed as 3.0-3.5 and its color turned to red-brown. In order to raise the $\mathrm{pH}$ to $4.5,1 \% \mathrm{NaOH}$ solution in ethanol was added and the mixture was stirred in a water bath at $50-55^{\circ} \mathrm{C}$ for $15 \mathrm{~min}$. The precipitated complexes were filtered while they were hot, washed with water, ethanol and diethyl ether and dried at $100{ }^{\circ} \mathrm{C}$. The colors, yields and melting point of the compounds are given in table 1 .

\section{RESULTS AND DISCUSSION}

In this study, starting with methylcyclohexylketone(1-acetyl-1-cyclohexene), anti-1-acetyl-1-cyclohexenylglyoxime was carried first by oxidation of the methyl group to the isonitroso group and, subsequently, conversion of $\mathrm{C}$ $=\mathrm{O}$ to the oxime by condensation with hydroxylammonium chloride, as given in the literature ${ }^{18}$. Chlorination of this compound in chloroform afforded anti-1-acetyl-1-cyclohexenylchloroglyoxime $\left(\mathrm{C}_{8} \mathrm{H}_{11} \mathrm{ClN}_{2} \mathrm{O}_{2}\right)$, an acceptable starting material to obtain various unsymmetrically substituted 1-acetyl-1cyclohexenylglyoxime(Figure 1).

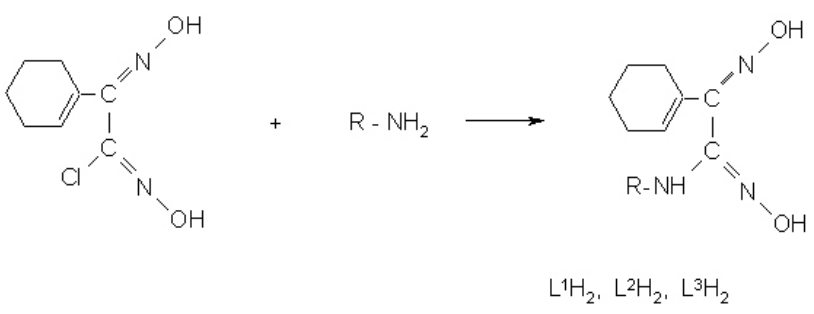

Fig. 1. Ligand Formula: $\mathrm{R}^{1}=\mathrm{C}_{6} \mathrm{H}_{5}-, \mathrm{R}^{2}=\mathrm{C}_{6} \mathrm{H}_{5}-\mathrm{CH}_{2}-, \quad \mathrm{R}^{3}=\mathrm{p}-\mathrm{CH}_{3}-\mathrm{C}_{6} \mathrm{H}_{4}-$ 
J. Chil. Chem. Soc., 54, No 2 (2009) 2).

The reaction of $\mathrm{C}_{8} \mathrm{H}_{11} \mathrm{ClN}_{2} \mathrm{O}_{2}$ with three different arylamines in ethanol at $-15^{\circ} \mathrm{C}$ gave three new substituted amino-1-acetyl-1-cyclohexenylglyoximes (Figure

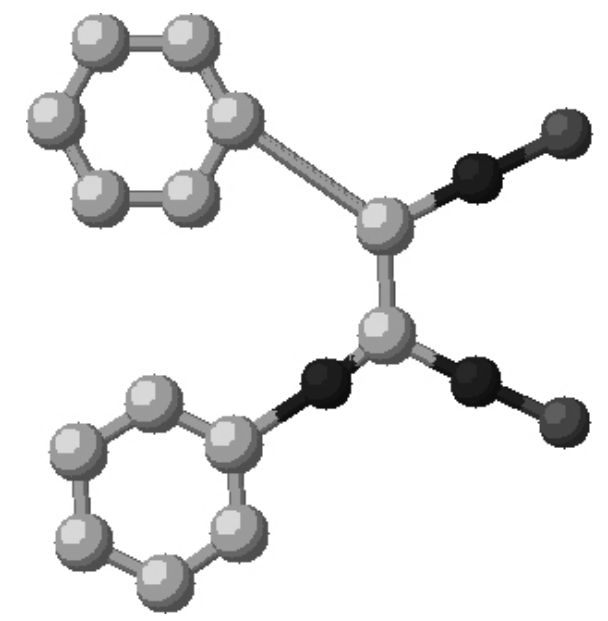

Fig.1a. Three dimensional structure of L1; R : C6H5-

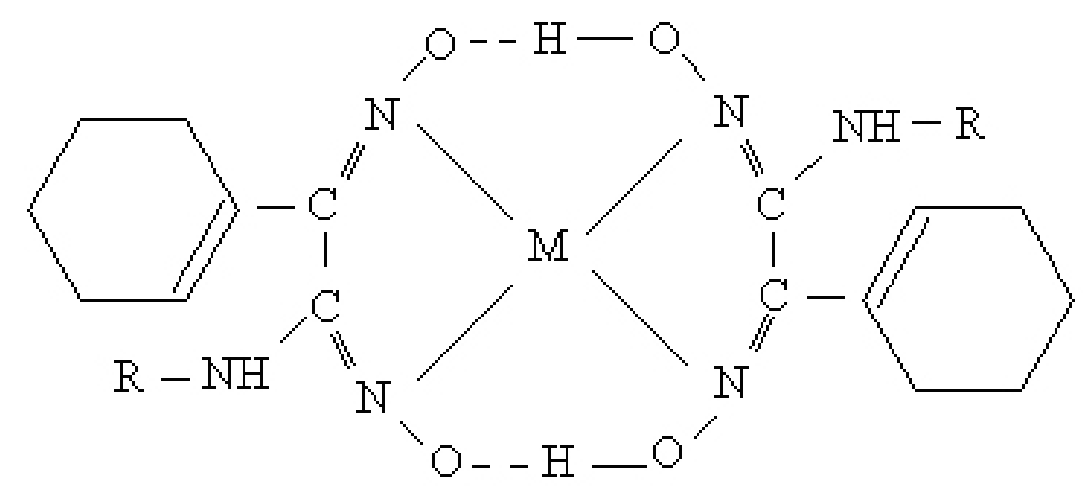

Fig. 2. Square-planar metal complexes of anti- and cis- complexes; $\mathrm{R} 1=\mathrm{C} 6 \mathrm{H} 5-$, $\mathrm{R} 2=\mathrm{C} 6 \mathrm{H} 5-\mathrm{CH} 2-, \mathrm{R} 3=\mathrm{p}-\mathrm{CH} 3-\mathrm{C} 6 \mathrm{H} 4-$

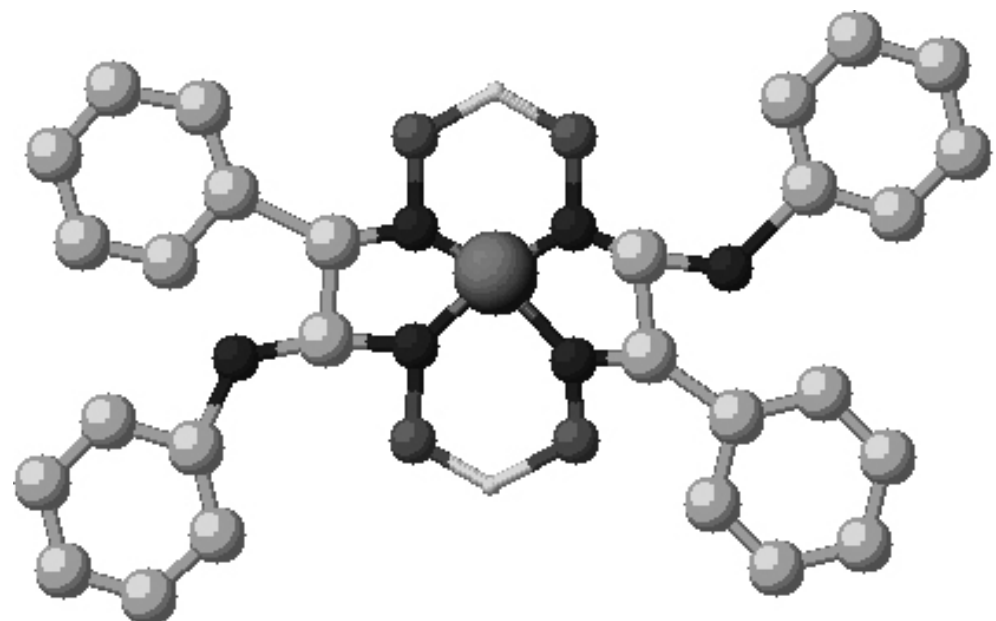

Fig.2a. Three dimensional structure of [Ni(HL1)2], trans form; $\mathrm{R}=\mathrm{C} 6 \mathrm{H} 5$ - 
Table 1. ${ }^{1} \mathrm{H}$ n.m.r. spectra of the ligands and $\left[\mathrm{Ni}\left(\mathrm{L}^{2}\right)_{2}\right]$ in $\mathrm{DMSO}-\mathrm{d}_{6} \delta$ (p.p.m.)

\begin{tabular}{|c|c|c|c|c|c|c|}
\hline Compounds & $\mathrm{O}-\mathrm{H} \ldots . . \mathrm{O}^{\mathrm{a}}$ & $\mathrm{O}-\mathrm{H}^{\mathrm{a}}$ & $\mathrm{O}-\mathrm{H}^{\mathrm{a}}$ & $\mathrm{H}^{\mathrm{a}}$ & $\mathrm{N}-\mathrm{H}^{\mathrm{a}}$ & Other \\
\hline $\mathrm{L}^{1} \mathrm{H}_{2}$ & - & $\begin{array}{c}11.95 \\
(1 \mathrm{H}) \mathrm{s}\end{array}$ & $\begin{array}{c}10.62 \\
(1 \mathrm{H}) \mathrm{s}\end{array}$ & $\begin{array}{c}8.15-6.85 \\
(14 \mathrm{H}) \mathrm{m}\end{array}$ & $\begin{array}{c}8.65 \\
(1 \mathrm{H}) \mathrm{s}\end{array}$ \\
\hline $\mathrm{L}^{2} \mathrm{H}_{2}$ & - & $\begin{array}{c}12.05 \\
(1 \mathrm{H}) \mathrm{s}\end{array}$ & $\begin{array}{c}10.02 \\
(1 \mathrm{H}) \mathrm{s}\end{array}$ & $\begin{array}{c}7.95-7.35 \\
(14 \mathrm{H}) \mathrm{m}\end{array}$ & $\begin{array}{c}6.96 \\
(1 \mathrm{H}) \mathrm{s}\end{array}$ & $\begin{array}{c}4.25-4.20\left(-\mathrm{CH}_{2}\right) \\
(2 \mathrm{H}) \mathrm{m}\end{array}$ \\
\hline$\left[\mathrm{Ni}\left(\mathrm{L}^{2}\right)_{2}\right]$ & 14.15 & & & $7.55-7.05$ & 8.05 & $4.30-4.25\left(-\mathrm{CH}_{2}\right)$ \\
$(4 \mathrm{H}) \mathrm{m}^{(28 \mathrm{H}) \mathrm{m}}$ & $(2 \mathrm{H}) \mathrm{m}$ & $\begin{array}{c}8.55 \\
(1 \mathrm{H}) \mathrm{s}\end{array}$ \\
\hline $\mathrm{L}^{3} \mathrm{H}_{2}$ & - & 11.90 & 10.35 & $7.80-6.55$ & $(13 \mathrm{H}) \mathrm{m}$ & $(3 \mathrm{H}) \mathrm{s}$ \\
\hline
\end{tabular}

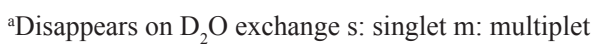

Table 2. Colors, molecular weights, magnetic moments, m.p.s, yield and elemental analytical results for the ligands and their complexes

\begin{tabular}{|c|c|c|c|c|c|c|c|c|}
\hline \multirow{2}{*}{ Compounds } & \multirow{2}{*}{$\begin{array}{l}\text { Color } \\
\text { and } \\
\text { M.W }\end{array}$} & \multirow{2}{*}{$\begin{array}{l}\text { Yield } \\
(\%)\end{array}$} & \multirow{2}{*}{$\begin{array}{c}\text { M.p. } \\
\left({ }^{\circ} \mathrm{C}\right) \\
\text { (dec) }\end{array}$} & \multirow{2}{*}{$\mu_{\text {eff }}(B M)^{i}$} & \multicolumn{4}{|c|}{ Calcd. (Found) \% } \\
\hline & & & & & C & $\mathbf{H}$ & $\mathbf{N}$ & $\mathbf{M}$ \\
\hline $\mathrm{L}^{1} \cdot \mathrm{H}_{2}$ & \multirow[b]{2}{*}{$\begin{array}{c}\text { Yellow } \\
259\end{array}$} & \multirow[b]{2}{*}{80} & \multirow[b]{2}{*}{105} & \multirow[b]{2}{*}{ - } & \multirow[b]{2}{*}{$\begin{array}{c}64.86 \\
(64.75)\end{array}$} & \multirow[b]{2}{*}{$\begin{array}{c}6.56 \\
(6.50)\end{array}$} & \multirow[b]{2}{*}{$\begin{array}{c}16.22 \\
(16.11)\end{array}$} & \multirow[b]{2}{*}{ - } \\
\hline $\mathrm{C}_{14} \mathrm{H}_{17} \mathrm{~N}_{3} \mathrm{O}_{2}$ & & & & & & & & \\
\hline$\left[\mathrm{Ni}\left(\mathrm{HL}^{1}\right)_{2}\right]$ & \multirow{2}{*}{$\begin{array}{c}\text { Red } \\
574,7\end{array}$} & \multirow[b]{2}{*}{83} & \multirow[b]{2}{*}{195} & \multirow[b]{2}{*}{ Dia } & \multirow[b]{2}{*}{$\begin{array}{c}58.46 \\
(58.50)\end{array}$} & \multirow[b]{2}{*}{$\begin{array}{c}5.57 \\
(5.45)\end{array}$} & \multirow[b]{2}{*}{$\begin{array}{c}14.61 \\
(14.40)\end{array}$} & \multirow{2}{*}{$\begin{array}{c}10.21 \\
(10.18)\end{array}$} \\
\hline $\mathrm{C}_{28} \mathrm{H}_{32} \mathrm{NiN}_{6} \mathrm{O}_{4}$ & & & & & & & & \\
\hline$\left[\mathrm{Cu}\left(\mathrm{HL}^{1}\right)_{2}\right]$ & \multirow{2}{*}{$\begin{array}{c}\text { Dark } \\
\text { Brown } \\
579,5\end{array}$} & \multirow{2}{*}{72} & \multirow{2}{*}{173} & \multirow{2}{*}{1.20} & \multirow{2}{*}{$\begin{array}{c}57.98 \\
(57.68)\end{array}$} & \multirow{2}{*}{$\begin{array}{c}5.52 \\
(5.45)\end{array}$} & \multirow{2}{*}{$\begin{array}{c}14.50 \\
(14.33)\end{array}$} & \multirow{2}{*}{$\begin{array}{c}10.96 \\
(10.85)\end{array}$} \\
\hline $\mathrm{C}_{28} \mathrm{H}_{32} \mathrm{CuN}_{6} \mathrm{O}_{4}$ & & & & & & & & \\
\hline $\mathrm{L}^{2} \cdot \mathrm{H}_{2}$ & \multirow{2}{*}{$\begin{array}{c}\text { Cream } \\
273\end{array}$} & \multirow{2}{*}{80} & \multirow{2}{*}{130} & \multirow{2}{*}{-} & \multirow{2}{*}{$\begin{array}{c}65.93 \\
(65.81)\end{array}$} & 6.96 & 15.38 & - \\
\hline $\mathrm{C}_{15} \mathrm{H}_{19} \mathrm{~N}_{3} \mathrm{O}_{2}$ & & & & & & $(6.82)$ & $(15.25)$ & \\
\hline$\left[\mathrm{Ni}\left(\mathrm{HL}^{2}\right)_{2}\right]$ & Red & 85 & 190 & Dis & 59.78 & 5.97 & 13.94 & 9.74 \\
\hline $\mathrm{C}_{30} \mathrm{H}_{36} \mathrm{NiN}_{6} \mathrm{O}_{4}$ & 602,7 & 85 & 190 & Dia & (58.99) & (5.78) & (13.69) & $(9.70)$ \\
\hline$\left[\mathrm{Cu}\left(\mathrm{HL}^{2}\right)_{2}\right]$ & $\begin{array}{l}\text { Dark } \\
\text { Brown }\end{array}$ & 75 & 175 & 144 & 59.26 & 5.93 & 13.83 & 10.45 \\
\hline $\mathrm{C}_{30} \mathrm{H}_{36} \mathrm{CuN}_{6} \mathrm{O}_{4}$ & 607,5 & & & 1.44 & $(59.15)$ & $(5.86)$ & $(13.70)$ & (10.37) \\
\hline $\mathrm{L}^{3} \cdot \mathrm{H}_{2}$ & Cream & 85 & 123 & _- & 65.93 & 6.96 & 15.38 & _- \\
\hline $\mathrm{C}_{15} \mathrm{H}_{19} \mathrm{~N}_{3} \mathrm{O}_{2}$ & & & & & $(65.45)$ & $(6.86)$ & $(15.27)$ & \\
\hline$\left[\mathrm{Ni}\left(\mathrm{HL}^{3}\right)_{2}\right]$ & Red & 78 & 235 & $\mathrm{Dia}$ & 59.78 & 5.97 & 13.94 & 9.74 \\
\hline $\mathrm{C}_{30} \mathrm{H}_{36} \mathrm{NiN}_{6} \mathrm{O}_{4}$ & 602,7 & 18 & 235 & Dia & $(59.60)$ & $(5.63)$ & (13.63) & $(9.62)$ \\
\hline$\left[\mathrm{Cu}\left(\mathrm{HL}^{3}\right)_{2}\right]$ & $\begin{array}{c}\text { Dark } \\
\text { Brown }\end{array}$ & 70 & 185 & 1.40 & 59.26 & 5.93 & 13.83 & 10.45 \\
\hline $\mathrm{C}_{30} \mathrm{H}_{36} \mathrm{CuN}_{6} \mathrm{O}_{4}$ & 607,5 & & & & $(59.46)$ & & & $(10.41)$ \\
\hline
\end{tabular}

${ }^{\mathrm{I}} \mu_{\text {eff }}$ : Magnetic moment, Dia . Diamagnetic.

Table 3. Characteristic i.r. bands of ligands and their complexes ${ }^{\mathrm{a}}(\mathrm{KBr}$ pellets $)$

\begin{tabular}{|c|c|c|c|c|c|c|c|}
\hline Compounds & $v(\mathrm{~N}-\mathrm{H})$ & $v(\mathrm{O}-\mathrm{H})$ & $v\left(\mathrm{C}-\mathrm{H}^{\mathrm{a}}\right)$ & $v(\mathrm{O}-\mathrm{H} \ldots . . \mathrm{O})$ & $v(\mathrm{C}=\mathrm{N})$ & $v(\mathrm{~N}-\mathrm{O})$ & $v(\mathrm{M}-\mathrm{N})$ \\
\hline $\mathrm{L}^{1} \cdot \mathrm{H}_{2}$ & $3370 \mathrm{~b}$ & $3170 \mathrm{~b}$ & $2860 \mathrm{~m}$ & & $1680 \mathrm{~s}$ & $980 \mathrm{~s}$ & \\
\hline$\left[\mathrm{Ni}\left(\mathrm{HL}^{1}\right)_{2}\right]$ & $3330 \mathrm{~b}$ & & $3070 \mathrm{~m}$ & $1650 \mathrm{w}$ & $1600 \mathrm{~s}$ & $940 \mathrm{~s}$ & $490 \mathrm{w}$ \\
\hline$\left[\mathrm{Cu}\left(\mathrm{HL}^{1}\right)_{2}\right]$ & $3310 \mathrm{~b}$ & & $3070 \mathrm{~m}$ & $1640 \mathrm{w}$ & $1610 \mathrm{~s}$ & $930 \mathrm{~s}$ & $480 \mathrm{w}$ \\
\hline $\mathrm{L}^{2} \cdot \mathrm{H}_{2}$ & $3420 \mathrm{~b}$ & $3320 \mathrm{~b}$ & $2890 \mathrm{~m}$ & & $1610 \mathrm{~s}$ & $960 \mathrm{~s}$ & \\
\hline$\left[\mathrm{Ni}\left(\mathrm{HL}^{2}\right)_{2}\right]$ & $3380 \mathrm{~b}$ & & $3050 \mathrm{~m}$ & $1710 \mathrm{w}$ & $1630 \mathrm{~s}$ & $950 \mathrm{~s}$ & $495 \mathrm{w}$ \\
\hline$\left[\mathrm{Cu}\left(\mathrm{HL}^{2}\right)_{2}\right]$ & $3370 \mathrm{~b}$ & & $3070 \mathrm{~m}$ & $1700 \mathrm{w}$ & $1620 \mathrm{~s}$ & $940 \mathrm{~s}$ & $500 \mathrm{w}$ \\
\hline $\mathrm{L}^{3} \cdot \mathrm{H}_{2}$ & $3370 \mathrm{~b}$ & $3110 \mathrm{~b}$ & $2900 \mathrm{~m}$ & & $1610 \mathrm{~s}$ & $970 \mathrm{~s}$ & \\
\hline$\left[\mathrm{Ni}\left(\mathrm{HL}^{3}\right)_{2}\right]$ & $3430 \mathrm{~b}$ & & $3050 \mathrm{~m}$ & $1720 \mathrm{w}$ & $1600 \mathrm{~s}$ & $950 \mathrm{~s}$ & $490 \mathrm{w}$ \\
\hline$\left[\mathrm{Cu}\left(\mathrm{HL}^{3}\right)_{2}\right]$ & $3420 \mathrm{~b}$ & & $3050 \mathrm{~m}$ & $1710 \mathrm{w}$ & $1620 \mathrm{~s}$ & $940 \mathrm{~s}$ & $500 \mathrm{w}$ \\
\hline
\end{tabular}


Table 4. TGA data of the complexes

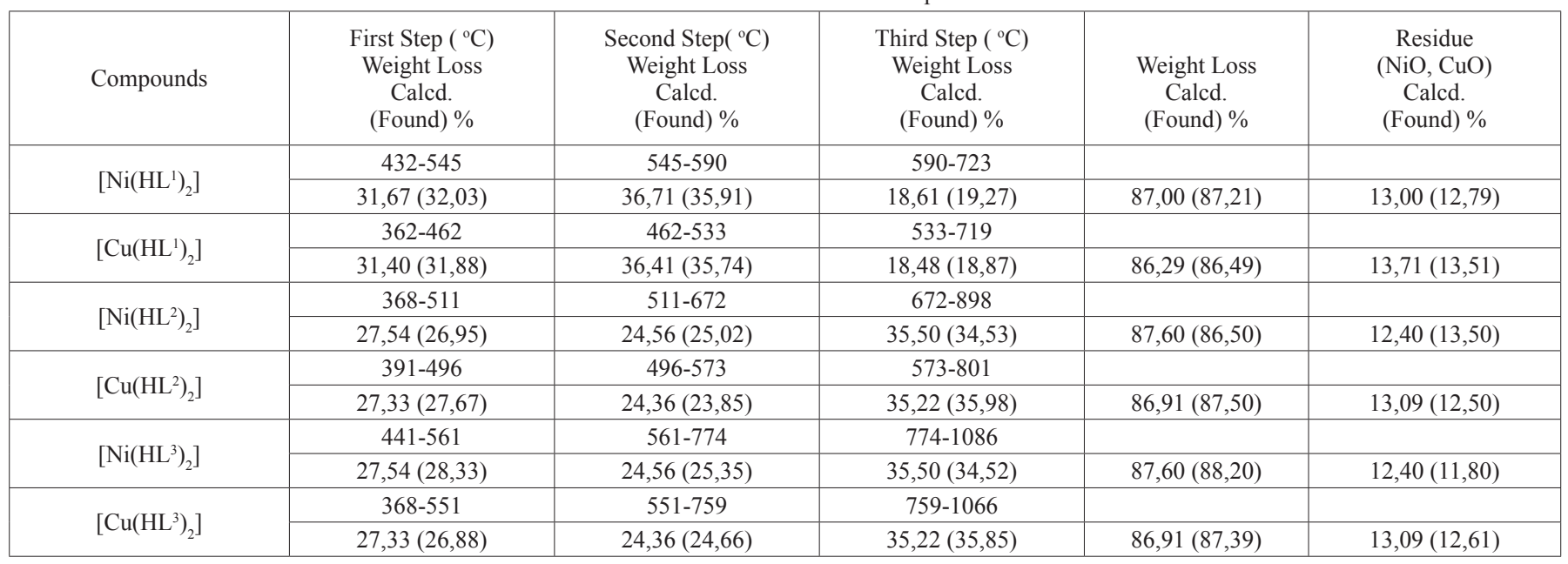

${ }^{1} H$-n.m.r. spectra of the ligands

In the ${ }^{1} \mathrm{H}-$-n.m.r. spectra, two different $-\mathrm{OH}$ peaks were seen for these ligands (Table 1). These two deuterium exchangeable singlets correspond to two non equivalent structures which indicate the anti-configuration such as cis and trans - form of this compound ${ }^{17,19-20}$. The chemical shift of the $\mathrm{O}-\mathrm{H}$ protons is seen at $11.90-12.05 \mathrm{ppm}$ and the N-H protons at $6.96-8.65 \mathrm{ppm}$. The losing of these peaks with the addition of $\mathrm{D}_{2} \mathrm{O}$ to the solution guides that the observed chemical shifts belong to the protons of $\mathrm{O}-\mathrm{H}$ and $\mathrm{N}-\mathrm{H}$ groups. ${ }^{1} \mathrm{H}-$-n.m.r. for $\left.\mathrm{L}^{2} \mathrm{H}_{2}: 6.96 \mathrm{ppm}(\mathrm{N}-\mathrm{H}, 1 \mathrm{H}), 4.25 \mathrm{ppm}, \mathrm{CH}_{2}, 2 \mathrm{H}\right)$.

\section{${ }^{1} H$-n.m.r. spectra of the complexes}

The solubility of the complexes of the three new unsymmetrical ligands is not enough to obtain ${ }^{1} \mathrm{H}$-n.m.r. spectra in solution except $\left[\mathrm{Ni}\left(\mathrm{HL}^{2}\right)_{2}\right]$. The proton n.m.r. spectrum of this diamagnetic complex indicates the formation of $\mathrm{O}-\mathrm{H} \ldots \mathrm{H}$ bridge by the strong shift of the peak of complex at $14.15 \mathrm{ppm}$ and this obtained data were contrary to the $\mathrm{L}^{1} \cdot \mathrm{H}_{2}{ }^{10,20}$. These values were given as $4.30 \mathrm{ppm}\left(-\mathrm{CH}_{2}, 4 \mathrm{H}\right)$. for $\mathrm{Ni}(\mathrm{II})$ complex. In conclusion of the unsymmetry in the ligands, the complexes are accepted to form two isomers (Fig 2). TLC (silicagel-G) was employed with different solvent mixtures and varying polarities, but only one spot appears in each case. This result implies that the formation of only one isomer is possible under these reaction conditions. The geometric isomerism of $\left[\mathrm{Ni}\left(\mathrm{HL}^{1}\right)_{2}\right]$ can be inferred from the ${ }^{1} \mathrm{H}$-n.m.r. spectrum, since the alternative chemical environments will show two $\mathrm{O}-\mathrm{H} \cdots \mathrm{O}$ bridge protons in the cis-form, but only one of them is in the trans-structure. The observed spectrum has only one resonance at $14.15 \mathrm{ppm}$ implying the trans-form of complex.

\section{Magnetic properties}

Magnetic susceptibility measurement provides information to characterize the structure as shown in Table 2. The mononuclear Ni(II) complexes of these ligands are diamagnetic as expected for $\mathrm{a} \mathrm{d}^{8}$ metal ion in a square planer field ${ }^{20,21}$. The $\mathrm{Cu}(\mathrm{II})$ complexes at $20^{\circ} \mathrm{C}$ are paramagnetic, $\mu_{\text {eff }}=1.20-1.44$ $\mathrm{BM}$.

\section{Conductivity measurements}

The molar conductance values of the synthesized ligands and their $\mathrm{Ni}(\mathrm{II})$ and $\mathrm{Cu}(\mathrm{II})$ complexes were measured and by the way it was seen that all the complexes are non-electrolytes.

\section{I. r. spectra of ligands and complex}

In the i.r. spectra of the ligands, $-\mathrm{NH}\left(3370-3420 \mathrm{~cm}^{-1}\right), \mathrm{OH}(320-3110$ $\left.\mathrm{cm}^{-1}\right), \mathrm{C}=\mathrm{N}\left(1680-1610 \mathrm{~cm}^{-1}\right)$ and NO $\left(980-960 \mathrm{~cm}^{-1}\right)$ stretches appear at frequencies expected for substituted glyoxime ${ }^{12,18,21}$ (Table 3 ). The characteristic i.r. absorptions of the complexes are given in Table 3. The range of the metalligand 1:2. From the results it can be said that $\mathrm{Ni}(\mathrm{II})$ and $\mathrm{Cu}(\mathrm{II})$ compounds were square-planar coordination as it is seen from Figure 2.. The i.r. spectra of the complexes support these structures by weak bending vibration of the $\mathrm{O}-\mathrm{H}$ $\cdots O$ bridges around $1640-1720 \mathrm{~cm}^{-1}$ and the shift of the $\mathrm{C}=\mathrm{N}$ vibration to lower frequencies at $1600-1630 \mathrm{~cm}^{-1}$ due to $\mathrm{N}, \mathrm{N}$-metal coordination ${ }^{12,22}$.

\section{TGA Analysis of metal complexes}

The TGA curves for the $\mathrm{Ni}(\mathrm{II})$ and $\mathrm{Cu}(\mathrm{II})$ complexes were obtained at a heating rate of $10^{\circ} \mathrm{C} / \mathrm{min}$ in a nitrogen atmosphere between the temperature range of $362-1086^{\circ} \mathrm{C}$. It was seen from the TGA results that decomposition of $\mathrm{Ni}(\mathrm{II})$ and $\mathrm{Cu}(\mathrm{II})$ complexes began between $362-441^{\circ} \mathrm{C}$ and finished between 728-1086 ${ }^{\circ} \mathrm{C}$. $\mathrm{Ni}(\mathrm{II})$ and $\mathrm{Cu}(\mathrm{II})$ complexes decompose to $\mathrm{NiO}$ and $\mathrm{CuO}$ in 3 steps in the temperature ranges. These results showed similarity with the results of other literature ${ }^{23-26}$.

\section{ACKNOWLEDGEMENT}

The authors are greatefull for the kind financial support provided by Selcuk University Research Foundation (SUAF).

\section{REFERENCES}

1. G. N. Schrauzer, R. J. Windgassen and J. Kohnle, Chem. Ber., 98, 3324, (1965).

2. A. Chakravorty, Coord. Chem. Rev., 13, 1, (1974).

3. B. G. Brown, Prog. Inorg. Chem., 18, 17, (1973).

4. T. W. Thomas and A. E. Underhil, Chem. Soc. Rev., 1, 99, (1972).

5. A. E. Underhill, D. M. Watkins and R. Petring, Inorg. Nucl. Chem.Lett., 9, 1269, (1973).

6. G. İrez and Ö. Bekaroğlu, Synth. React. Inorg. M., 13, 781, (1983).

7. S. Serin and Ö. Bekaroğlu, Z. Anorg. Allg. Chem., 496, 197, (1983).

8. Y. Gök and S. Serin, Synth. React. Inorg. M., 18, 975, (1988).

9. A. İ. Pekacar, B. Mercimek and E. Özcan, Synth. React. Inorg. M., 27, 455, (1997).

10. H. Uçan and R. Mirzaoğlu, Synth. React. Inorg. M., 20, 437, (1990).

11. H. C. Sevindir, R. Mirzaoğlu, E. Özcan, Ş. Ertul, E. Güler, Synth. React. Inorg. M., 24, 613, (1994).

12. A. İ. Pekacar and E. Özcan, Macromolecular Reports, A32, 1161, (1995).

13. Y. Gök and E. Özcan, Transit. Metal Chem.,16, 393, (1991).

14. V. Ahsen, Ö. Bekaroğlu, Synth. React. Inorg. M.., 15, (1), 61, (1985).

15. M. Koçak and Ö. Bekaroğlu, Synth. React. Inorg. M., 14, (5), 689, (1984).

16. F. Karipcin, F. Arabal1, J. Chil Chem. Soc., 51, 982-985, (2006)

17. A. Gül and Ö. Bekaroğlu, J. Chem. Soc. Dalton Trans., 2537, (1983).

18. J. V. Buracevich, A. M. Love and G. P. Volpp, J. Org. Chem., 36, 1 (1973).

19. V. Ahsen, F. Gökçeli and Ö. Bekaroğlu, J. Chem. Soc. Dalton Trans., 1827, (1987).

20. M. Koçak and Ö. Bekaroğlu, Synth. React. Inorg. M., 15, 479, (1985). 
21. H. C. Sevindir, Synth. React. Inorg. M., 30, 183, (2000).

22. H. C. Sevindir, R. Mirzaoğlu, Macromolecular Reports, A31, 399, (1994).

23. H. Arslan, J. Them. Anal. Calorim., 66, 399, (2001).
24. H. Arslan, N. Ozpozan and T. Ozpozan, Thermochim. Acta, 329, 57, (1999)

25. H. Arslan and N. Külcü, Turk. J. Chem, 27, 55, (2003).

26. E. Canpolat and M. Kaya, Turk. J. Chem, 28, 235, (2004). 